\title{
Sequencing and expression analysis of hepcidin mRNA in donkey (Equus asinus) liver ${ }^{1}$
}

\author{
José P. Oliveira-Filho², Jessica A. Marques², Paulo Henrique J. Cunha ${ }^{3}$, Gildenor X. \\ Medeiros $^{4}$, Franklin Riet-Correa ${ }^{4}$, Vânia Maria V. Machado ${ }^{2}$ and Alexandre S. Borges ${ }^{2 *}$
}

\begin{abstract}
Oliveira-Filho J.P., Marques J.A., Cunha P.H.J., Medeiros G.X., Riet-Correa F., Machado V.M.V. \& Borges A.S. 2012. Sequencing and expression analysis of hepcidin mRNA in donkey (Equus asinus) liver. Pesquisa Veterinária Brasileira 32(10):1050-1054. Departamento de Clínica Veterinária, Faculdade de Medicina Veterinária e Zootecnia, Universidade Estadual Paulista, Campus de Botucatu, Distrito de Rubião Júnior s/n, Botucatu, SP 18618-000, Brazil. E-mail: asborges@fmvz.unesp.br

The hypoferremia that is observed during systemic inflammatory processes is mediated by hepcidin, which is a peptide that is mainly synthesized in the livers of several mammalian species. Hepcidin plays a key role in iron metabolism and in the innate immune system. It's up-regulation is particularly useful during acute inflammation, and it restricts the iron availability that is necessary for the growth of pathogenic microorganisms. In this study, the hepcidin mRNA of Equus asinus has been characterized, and the expression of donkey hepcidin in the liver has been determined. The donkey hepcidin sequence has an open reading frame (ORF) of 261 nucleotides, and the deduced corresponding protein sequence has 86 amino acids. The amino acid sequence of donkey hepcidin was most homologous to Equus caballus (98\%). The mature donkey hepcidin sequence ( 25 amino acids) was $100 \%$ homologous to the equine mature hepcidin and has eight conserved cysteine residues that are found in all of the investigated hepcidin sequences. The expression profile of donkey hepcidin in the liver was high and was similar to the reference gene expression. The donkey hepcidin sequence was deposited in GenBank ${ }^{\mathrm{TM}}$ (HQ902884) and may be useful for additional studies on iron metabolism and the inflammatory process in this species.
\end{abstract}

INDEXS TERMS: Hepcidin, mRNA, sequencing, expression, Equus asinus.

RESUMO-- [Sequenciamento e expressão do RNA mensageiro da hepcidina no fígado de jumentos (Equus asinus).] A hipoferremia observada durante os processos inflamatórios sistêmicos é mediada pela hepcidina, um peptídeo que é sintetizado predominantemente no fígado de mamíferos. A hepcidina desempenha um papel chave no metabolismo do ferro e no sistema imune. 0 aumento da expressão da hepcidina é particularmente útil durante a inflamação

\footnotetext{
${ }^{1}$ Received on August 10, 2011.

Accepted for publication on April 15, 2012.

2 Departamento de Clínica Veterinária, Faculdade de Medicina Veterinária e Zootecnia, Universidade Estadual Paulista (Unesp), Campus de Botucatu, Distrito de Rubião Júnior s/n, Botucatu, SP 18618-000, Brazil. *Corresponding author: asborges@fmvz.unesp.br

${ }^{3}$ Departamento de Medicina Veterinária, Escola de Veterinária, Universidade Federal de Goiás (UFG), Campus Samambaia (Campus II), Cx. Postal 131, Goiânia, GO 74001-970, Brazil.

${ }^{4}$ Hospital Veterinário, Campus de Patos da Universidade Federal de Campina Grande (UFCG), Patos, PB 58700-000, Brazil.
}

aguda, pois restringe a disponibilidade de ferro, necessária para o crescimento de microorganismos patogênicos. Neste estudo, o RNA mensageiro da hepcidina asinina foi caracterizado e sua expressão foi determinada em fígado de jumentos (Equus asinus). A sequência da hepcidina asinina tem uma janela de leitura de 261 nucleotídeos e a proteína correspondente é formada por 86 aminoácidos. A sequência de aminoácidos da hepcidina asinina foi mais homóloga à sequência da hepcidina equina (98\%). A hepcidina madura (25 aminoácidos) foi $100 \%$ idêntica à hepcidina madura equina e possuía as oito cisteínas conservadas nas demais sequências de hepcidinas analisadas. 0 perfil de expressão da hepcidina no fígado de jumentos saudáveis foi alto e similar ao perfil de expressão do gene de referência. A sequência da hepcidina asinina foi depositada no GenBank ${ }^{\mathrm{TM}}$ (HQ902884) e será útil para o desenvolvimento de estudos adicionais sobre o metabolismo de ferro e inflamação nesta espécie.

TERMOS DE INDEXAÇÃO: Hepcidina, mRNA, sequenciamento e expressão gênica, Equus asinus. 


\section{INTRODUCTION}

Hepcidin is a peptide of 25 amino acids (aa) in length that is primarily expressed in the liver. Hepcidin has activity against some Gram-positive and Gram-negative bacteria and yeasts (Krause et al. 2000, Park et al. 2001) and plays an important role in the metabolism of iron in the mammalian species (Ganz \& Nemeth 2006). Hepcidin binds to the iron exporter ferroportin (Fpn) and promotes its internalization and degradation (De Domenico et al. 2009). Thus, there is an inhibition of the iron influx into plasma from ferroportin-rich tissues and a decrease in dietary iron absorption (Ganz \& Nemeth 2006). The resulting hypoferremia is a common response to systemic infections or generalized inflammatory disorders (Nemeth et al. 2004), and it primarily serves as a host defense mechanism that limits iron availability to invading microorganisms (Andrews 2004).

The hepcidin gene has been previously characterized in several mammalian species, e.g., humans (Krause et al. 2000), dog (Fry et al. 2004), swine (Sang et al. 2006), cattle (Hilton \& Lambert 2008), sheep (Badial et al. 2011), water buffalo (Khangembam \& Kumar 2011), and horse (Oliveira Filho et al. 2010); however, there are no reports concerning the donkey hepcidin sequence. Therefore, we describe the complete nucleotide sequence of the open reading frame (ORF) of donkey hepcidin and show differences between the donkey and horse nucleotide and protein sequences. A hepcidin expression analysis of the liver of a clinically healthy donkey was also performed.

\section{MATERIALS AND METHODS}

Liver tissue samples. Six adult donkeys (Equus asinus) were obtained from three farms and were used in this study. The donkeys were all sedated by an intravenous injection of xylazine hydrochloride $(1 \mathrm{mg} / \mathrm{kg}$ of body weight) and were administered local anesthesia ( $2 \mathrm{ml}$ of $2 \%$ lidocaine). Ultrasound-guided liver biopsies were obtained from the right $11^{\text {th }}$ or $12^{\text {th }}$ intercostal space in a line that had been drawn from the point of the shoulder to the tuber coxae. Liver biopsies were taken using a 14-G Tru-cut ${ }^{\circledR}$ biopsy needle (Biomedical, Italy). Immediately after harvesting, all of the biopsy samples were frozen in liquid nitrogen and stored at $-80^{\circ} \mathrm{C}$ until RNA purification. All experiments were carried out according to the Univ Estadual Paulista (Unesp) Institutional Animal Care and Use Committee (03/2010 CEUA).

RNA isolation, reverse transcription-polymerase chain reaction (RT-PCR) and sequence analysis. Total RNA was isolated from a donkey liver sample using the RNeasy ${ }^{\circledR}$ Mini Kit (Qiagen, USA), following the manufacturer's instructions. The relative purity and quality of the isolated RNA was determined by a Nanodrop ${ }^{\circledR} 2000$ Spectrophotometer (Thermo Scientific ${ }^{\mathrm{TM}}$, USA). Briefly, the total RNA, which had been treated with RQ1 RNase-Free DNase (Promega, USA) in order to eliminate genomic DNA from the samples, was used for first-strand cDNA synthesis. The cDNA was prepared using $500 \mathrm{ng}$ of total RNA per $60 \mu \mathrm{l}$ of the reaction solution using random hexamers and the ImProm-II ${ }^{\mathrm{TM}}$ Reverse Transcription System (Promega, USA), following the manufacturer's instructions. The RT-PCR was performed using primer sets that had previously been designed for the sequence of equine hepcidin (Oliveira Filho et al. 2010). The RT-PCR was performed in duplicate using $20.0-\mu \mathrm{l}$ reaction solution that contained $0.4 \mu \mathrm{M}$ of each primer, $2.0 \mu \mathrm{l}$ of template cDNA, $10.0 \mu \mathrm{l}$ of $\mathrm{GoTaq}^{\circledR}$ Green Master Mix (Promega, USA) and $6.4 \mu \mathrm{l}$ of nuclease-free wa- ter. In addition, a "no template" control was performed in order to demonstrate the absence of contamination. The PCR conditions were established as follows: initial denaturation at $94^{\circ} \mathrm{C}$ for $5 \mathrm{~min}$ and 35 cycles at $94^{\circ} \mathrm{C}$ for $15 \mathrm{~s}$ (denaturation), $60^{\circ} \mathrm{C}$ for $30 \mathrm{~s}$ (annealing) and $72^{\circ} \mathrm{C}$ for $60 \mathrm{~s}$ (extension) and then a final extension at $72^{\circ} \mathrm{C}$ for $5 \mathrm{~min}$.

The PCR products were analyzed via 1.5\% agarose gel electrophoresis (Invitrogen ${ }^{\circledR}$, USA), stained by GelRed ${ }^{\mathrm{TM}}$ (Biotium $^{\mathrm{TM}}$, USA) and visualized under an ultraviolet light. The molecular weights of the PCR products were estimated by comparing them to a known molecular weight marker of 100 bp in length (Norgen ${ }^{\circledR}$, Canada). The PCR products with predicted sizes of $\sim 450 \mathrm{bp}$ were purified using the QIAquick ${ }^{\circledR}$ PCR Purification Kit (Qiagen ${ }^{\circledR}$, USA). An automated direct sequence analysis was performed in quadruplicate via 3500 Genetic Analyzers (Applied Biosystems ${ }^{\mathrm{TM}}$, USA) and the BigDye ${ }^{\circledR}$ Terminator v3.1 Cycle Sequencing Kit (Applied Biosystems $^{\mathrm{TM}}$, USA) using $5.0 \mu \mathrm{l}$ of each primer and $10.0 \mu \mathrm{l}$ of the PCR product. The sequences and electropherograms obtained were analyzed using Sequencing Analysis 5.3.1 software (Applied Biosystems $^{\mathrm{TM}}$, USA). The obtained sequence was blasted (http:// blast.ncbi.nlm.nih.gov/Blast.cgi) in order to verify sequence homology against equine hepcidin and six other mammalian hepcidin sequences that have previously been deposited in GenBank ${ }^{\mathrm{TM}}$ (http://www.ncbi.nlm.nih.gov/).

Expression analysis of hepatic donkey hepcidin by real-time RT-PCR (qRT-PCR). The primer sets that were used in the qRT-PCR (amplifying an $\sim 81$ bp (base pair) fragment of the hepcidin mRNA and an $\sim 86$ bp fragment of the $\beta$-actin mRNA as a reference gene) have previously been described (Oliveira Filho et al. 2010). The relative quantification of the donkey hepatic hepcidin mRNA was performed using the comparative Ct method $\left(2^{-\Delta \Delta C t}\right.$ method) for relative real-time PCR data processing (Livak \& Schmittgen 2001) via a 7500 Real-Time PCR System (Applied Biosystems $^{\mathrm{TM}}$, USA) and the Power SYBR ${ }^{\circledR}$ Green PCR Master Mix (Applied Biosystems ${ }^{\mathrm{TM}}$, USA). Each qRT-PCR reaction was performed in triplicate using 20.0- $\mu$ l reaction solutions, which contained $0.3 \mathrm{mM}$ of each forward and reverse primer, $2.0 \mu \mathrm{l}$ of template cDNA, $10.0 \mu \mathrm{l}$ of the qRT-PCR master mix and $6.8 \mu \mathrm{l}$ of nuclease-free water. In addition, two "no template" controls were included on each plate in order to demonstrate the absence of amplicon contamination. The PCR conditions were established as follows: initial denaturation at $95^{\circ} \mathrm{C}$ for $10 \mathrm{~min}$ and 40 cycles at $95^{\circ} \mathrm{C}$ for 15 $\mathrm{s}$ and $60^{\circ} \mathrm{C}$ for $60 \mathrm{~s}$, followed by a melting curve. The expression of basal donkey hepcidin mRNA was compared to the expression of $\beta$-actin mRNA.

\section{RESULTS}

The ultrasound-guided liver biopsies were safe and were successfully used to obtain purified RNA. No adverse effects were observed in the donkeys after the procedure. The A260/A280 of the isolated RNA exceeded 2.0 for all of the preparations, which indicates the purity of the RNA. The amplification of the cDNA using equine hepcidin primers worked well and facilitated the sequencing of the hepcidin that was obtained from the donkeys. The cDNA of the donkey hepcidin that is presented here is $354 \mathrm{bp}$ in length, which includes $19 \mathrm{bp}$ in the $5^{\prime}$-untranslated region (UTR) and $74 \mathrm{bp}$ in the 3'-UTR. The ORF of the obtained preprohepcidin sequence has 261 bp (Fig.1) and was submitted to the NCBI (accession number HQ902884). The base composition of the ORF L-strand consists of $20.7 \%$ adenine, $34.1 \%$ cytosine, $26.8 \%$ guanine, and $18.4 \%$ thymine. The nucleotide sequences of the preprohepcidin 


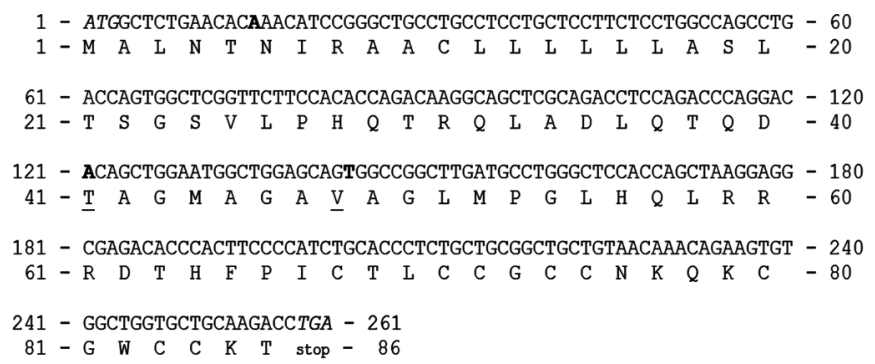

Fig.1. Open reading frame (top) and deduced amino acid (bottom) sequences of donkey hepcidin. Start and stop codons are in italics. Bold nucleotides and underlined amino acids indicate differences with equine sequence.

cDNA of donkey and equine (GQ_253624) exhibited a total difference of three nucleotides at positions 15, 121 and 143 , wherein the bases guanine, guanine and cytosine in the equine were replaced by adenine, adenine and thymine, respectively, in the donkey.

The donkey preprohepcidin protein sequence is 86 aa long and contains a putative 23 -aa-long signal peptide, a 38-aa-long pro-peptide region and a 25 -aa-long mature hepcidin peptide (Fig.2). The donkey and equine hepcidin sequences have similar putative signal peptide cleavage sites between a glycine $\left(\mathrm{G}^{23}\right)$ and serine $\left(\mathrm{S}^{24}\right)$ and similar putative propeptide cleavage recognition sites that consist of the motif HQLRRR ${ }^{56-61}$. Upon alignment, the donkey preprohepcidin amino acid sequence was observed to share a 98\% identity with the equine hepcidin (ACZ04924.1) and show two different amino acids at positions 41 (the threonine in the donkey sequence was replaced by alanine in the equine sequence) and 48 (the valine in the donkey sequence was replaced by alanine in the equine sequence). No insertions or deletions were observed between the donkey and the equine preprohepcidin sequences.

The donkey, equine and six other preprohepcidin amino acid sequences were aligned using the CLUSTAL X program (Larkin et al. 2007), and the phylogenetic analyses were conducted using MEGA4 software (Tamura et al. 2007). The evolutionary history was inferred using the neighbor-joining method (Saitou and Nei 1987), a complete deletion of gaps, and 1,000 bootstrap interactions (Felsenstein 1985) (Fig.3). The experimentally determined donkey hepcidin sequence

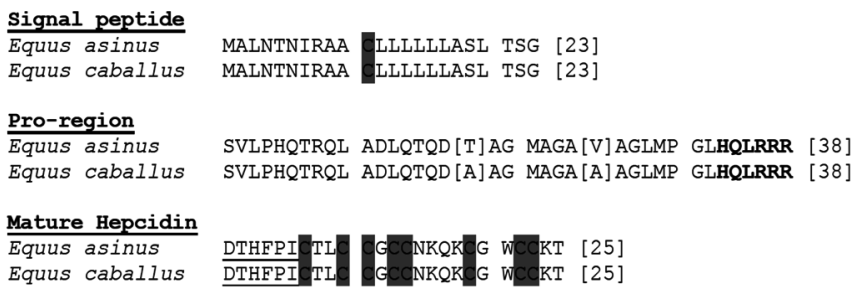

Fig.2. Amino acid sequence of the donkey and equine signal peptide, pro-region and mature hepcidin. Conserved cysteine (C) residues in the signal peptide and mature hepcidin are indicated in gray. Residues in parenthesis indicate amino acids different between both sequences. Bold sequence indicates the predicted furin cleavage site. Underlined residues indicate essential amino acid sequence for bidding to ferroportin. The sequence alignment was constructed using the Clustal X.

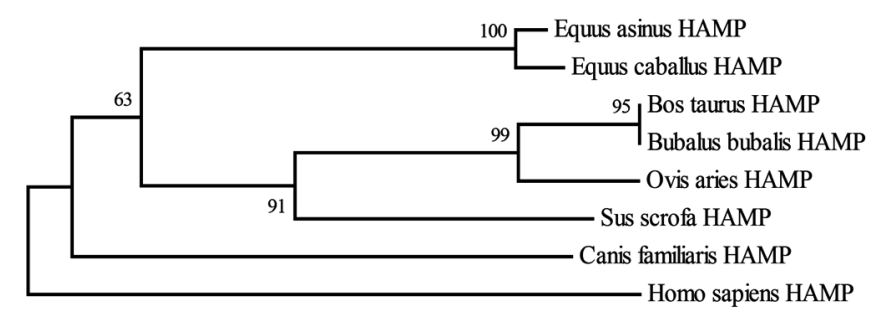

Fig.3. Phylogenic tree showing the relationship of the donkey hepcidin (HAMP) amino acid sequence with previously identified hepcidin sequences. The phylogeny was constructed using Clustal X program, and the evolutionary history was inferred using the Neighbor-Joining method. The numbers next to the branches show bootstrap majority consensus values on 1000 replicates in percent. All positions containing gaps and missing data were eliminated from the dataset. Phylogenetic analyses were conducted in MEGA4.

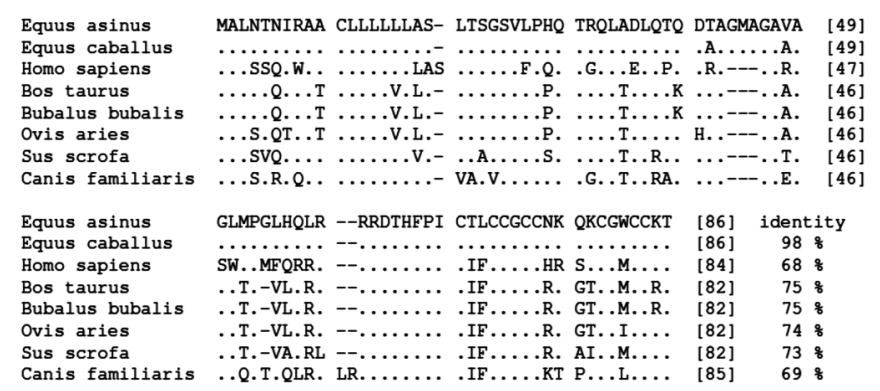

Fig.4. Alignment of amino acid sequence of donkey hepcidin (HQ902884) with hepcidin of different species. The sequence alignment was constructed using the Clustal X. NCBI accession number: Equus caballus, ACZ04924.1; Homo sapiens, NP066998.1; Bos taurus, AAI11659.1; Bubalus bubalis, ABY81280.2; Ovis aries, NP001182241.1; Sus scrofa, AAM77745.1 and Canis familiaris, NP001007141.1.

had a 75\% identity to Bos taurus (AAI11659.1) and Bubalus bubalis (ABY81280.2), 74\% to Ovis aries (NP001182241.1), $73 \%$ to Sus scrofa (AAM77745.1), 69\% to Canis familiaris (NP001007141.1) and 68\% to Homo sapiens (NP066998.1) (Fig.4). The putative 25-aa-long mature peptide sequence of donkey hepcidin is $100 \%$ identical to the equine mature hepcidin; $76 \%$ identical to the canine, porcine and human mature hepcidin sequences and $72 \%$ identical to the cattle and buffalo mature hepcidin sequences. Although the first six amino acids $^{62-67}$ that were observed in the donkey mature hepcidin sequence was highly conserved among the compared mammalian species, eight cysteine (C) residues in the mature hepcidin and an additional cysteine residue at position 11 of the preprohepcidin were also conserved in donkey hepcidin.

The equine hepcidin and $\beta$-actin mRNA primers (Oliveira Filho et al. 2010) that were used in the expression analysis of hepcidin mRNA donkey liver amplified specific transcripts, which were confirmed by melting curve profiles that were generated at the end of each run. Quantitative PCR analysis demonstrated that expression profile of donkey hepcidin in liver was high and was similar to the cycle threshold (CT) values that have been obtained for the $\beta$-actin housekeeping gene. 


\section{DISCUSSION}

Donkeys and horses belong to the order Perissodactyla, family Equidae and genus Equus (Grubb 1993), and although there are similar morphologic aspects between these two species, the mitochondrial DNA differences suggest that the evolutionary separation of these two species occurred around nine million years ago (Xu et al. 1996). In our study, the amino acid sequence of the hepcidin ORF of the donkey showed a greater identity (98\%) with the horse (Oliveira Filho et al. 2010) in comparison to other mammalian hepcidin sequences (Krause et al. 2000, Park et al. 2001, Fry et al. 2004, Sang et al. 2006, Hilton \& Lambert 2008, Badial et al. 2011, Khangembam \& Kumar 2011). Xu et al. (1996) also demonstrated an average identity of $98 \%$ (91.2-99.8\%) between the 13 mitochondrial DNA and amino acid sequences of the donkey and horse.

Human hepcidin is initially synthesized as a larger precursor protein (preprohepcidin) that undergoes two cleavages (the signal peptide and then the propeptide) before being secreted from the cell (Valore \& Ganz 2008). The horse hepcidin precursor protein also has three segments (signal peptide, pro-region and mature hepcidin) (Oliveira Filho et al. 2010). Similar to the horse, the donkey hepcidin precursor protein is divided into three segments. The number of amino acids in each of the segments and cleavage points of the donkey hepcidin protein are similar to the equine hepcidin. Furin is the proprotein convertase for the human hepcidin (Valore \& Ganz 2008), which is most likely also the case for horse hepcidin (Oliveira Filho et al. 2010). In addition, donkey and equine have the same putative propeptide cleavage motif, which is different from the cleavage motifs that are found in other hepcidin sequences, suggesting that furin may also be the proprotein convertase for donkey hepcidin.

As is the case for other species, the mature donkey hepcidin sequence is 25 -aa-long and is $100 \%$ homologous to the mature equine hepcidin. The first six amino acids ${ }^{62-67}$ that were observed in the mature donkey hepcidin and are conserved in other hepcidins (Krause et al. 2000, Park et al. 2001, Fry et al. 2004, Sang et al. 2006, Hilton \& Lambert 2008, Badial et al. 2011, Khangembam \& Kumar 2011) appear to be essential to the binding of ferroportin (Hilton $\&$ Lambert 2008). The mature donkey hepcidin sequence was observed to contain eight cysteines at amino acid positions that are absolutely conserved across mammalian species (Krause et al. 2000, Park et al. 2001, Fry et al. 2004, Sang et al. 2006, Hilton \& Lambert 2008, Badial et al. 2011, Khangembam \& Kumar 2011). These eight conserved residues are important for disulfide bonding and the maintenance of the structural shape of the hepcidin protein (Hunter et al. 2002, Fry et al. 2004). This result confirms that mature hepcidin sequences are highly conserved among mammalian species (Hilton \& Lambert 2008, Oliveira Filho et al. 2010).

The expression analysis of hepcidin mRNA from donkey liver by real-time PCR was performed with primers that had been previously designed for the equine hepcidin sequence (Oliveira Filho et al. 2010), and the specificity of these primers was tested via Blast analysis, resulting in a $100 \%$ identity and complete annealing to the sequenced donkey hepcidin gene. In addition, the amplification of specific transcripts was confirmed by melting curve profiles. Hepcidin was first identified as an antimicrobial peptide from human plasma ultrafiltrate (Krause et al. 2000) and urine (Park et al. 2001). Its expression levels in human (Krause et al. 2000) and equine (Oliveira Filho et al. 2010) livers are comparable to those of the glyceraldehyde 3-phosphate dehydrogenase (GAPDH) and $\beta$-actin housekeeping genes, respectively. This result is consistent with the findings of other authors that have shown that hepcidin is predominantly synthesized in the livers of dogs (Fry et al. 2004), pigs (Sang et al. 2006) and sheep (Badial et al. 2011).

In summary, to the best of our knowledge, this report is the first to describe the nucleotide and amino acid sequence (GenBank ${ }^{\mathrm{TM}}$ accession number HQ902884) of hepcidin and its expression in the livers of healthy donkeys. This sequence will be helpful for additional studies on iron metabolism and inflammatory processes in donkeys. Further research is needed to increase our knowledge concerning the role of hepcidin in the regulation of iron metabolism in donkeys.

Acknowledgements.- This study was supported by grants from Fundação de Amparo à Pesquisa do Estado de São Paulo (FAPESP, Proc.07/07344-6 e 10/00058-0). The first author has a grant from PNPD-MCT/CNPq/Finep, and the last author has a grant from Conselho Nacional de Desenvolvimento Científico e Tecnológico (CNPq).

\section{REFERENCES}

Andrews N.C. 2004. Anemia of inflammation: the cytokine-hepcidin link. J. Clin. Invest. 113:1251-1253.

Badial P.R., Oliveira Filho J.P., Cagnini D.Q., Cunha P.H.J., Araujo Jr J.P., Winand N.J. \& Borges A.S. 2011. Identification, characterization and expression analysis of hepcidin gene in sheep. Res. Vet. Sci. 90:443-450.

De Domenico I., Loa E., Warda D.M. \& Kaplana J. 2009. Hepcidin-induced internalization of ferroportin requires binding and cooperative interaction with Jak2. Proc. Natl Acad. Sci. 106:3800-3805.

Felsenstein J. 1985. Confidence limits on phylogenies: An approach using the bootstrap. Evol. 39:783-791.

Fry M.M., Liggett J.L. \& Baek S.K. 2004. Molecular cloning and expression of canine hepcidin. Vet. Clin. Pathol. 33:223-227.

Ganz T. \& Nemeth E. 2006. Iron imports IV. Hepcidin and regulation of body iron metabolism. Am. J. Physiol. Gastrointest. Liver Physiol. 290:199-203.

Grubb P. 1993. Order perissodactyla, p.369-372. In: Wildos D.E. \& Reeder D.M. (Eds), Mammal species of the world: A taxonomic and geographic reference. $2^{\text {nd }}$ ed. Smithsonian Institution, Washington, DC.

Hilton K.B. \& Lambert L.A. 2008. Molecular evolution and characterization of hepcidin gene products in vertebrates. Gene 415:40-48.

Hunter H.N., Fulton D.B., Ganz T. \& Vogel H.J. 2002. The solution structure of human hepcidin, a peptide hormone with antimicrobial activity that is involved in iron uptake and hereditary hemochromatosis. J. Biol. Chem. 277:37597-37603.

Khangembam V.C. \& Kumar A. 2011. Buffalo hepcidin: Characterization of cDNA and study of antimicrobial property. Vet. Res. Commun. 35:79-87.

Krause A., Neitz S., Mägert H.J., Schulz A., Forssmann W.G., Schulz-Knappe P. \& Adermann K. 2000. LEAP-1, a novel highly disulfide-bonded human peptide exhibits antimicrobial activity. FEBS Lett. 480:147-150.

Larkin M.A., Blackshields G., Brown N.P., Chenna R., McGettigan P.A., McWilliam H., Valentin F., Wallace I.M., Wilm A., Lopez R., Thompson J.D., Gibson T.J. \& Higgins D.G. 2007. Clustal W and Clustal X version 2.0. Bioinformatics 23:2947-2948. 
Livak K.J. \& Schmittgen T.D. 2001. Analysis of Relative Gene Expression Data Using Real- Time Quantitative PCR and the $2^{-\Delta \Delta C}$ T Method. Methods 25:402-408.

Nemeth E., Rivera S., Gabayan V., Keller C., Taudorf S., Pedersen B.K. \& Ganz T. 2004. IL-6 mediates hypoferremia of inflammation by inducing the synthesis of the iron regulatory hormone hepcidin. J. Clin. Invest. 13:1271-1276.

Oliveira Filho J.P., Badial P.R., Cunha P.H.J., Cruz T.F., Araujo Jr J.P., Divers T.J., Winand N.J. \& Borges A.S. 2010. Cloning, sequencing and expression analysis of the equine hecidin gene by real-time PCR. Vet. Immunol. Immunopathol. 135:34-42.

Park C.H., Valore E.V., Waring A.J. \& Ganz T. 2001. Hepcidin: a urinary antimicrobial peptide synthesized in the liver. J. Biol. Chem. 276:78067810 .
Saitou N. \& Nei M. 1987. The neighbor-joining method: A new method for reconstructing phylogenetic trees. Mol. Biol. Evol. 4:406-425.

Sang Y., Ramanathan B., Minton J.E., Ross C.R. \& Blecha F. 2006. Porcine liver-expressed antimicrobial peptides, hepcidin and LEAP-2: cloning and induction by bacterial infection. Dev. Comp. Immunol. 30:357-366.

Tamura K., Dudley J., Nei M. \& Kumar S. 2007. MEGA4: Molecular Evolutionary Genetics Analysis (MEGA) software version 4.0. Mol. Biol. Evol. 24:1596-1599.

Valore E.V. \& Ganz T. 2008. Posttranslational processing of hepcidin in human hepatocytes is mediated by the prohormone convertase furin. Blood Cells. Mol. Dis. 40:132-138.

Xu X., Gullberg A. \& Arnason U. 1996. The complete mitochondrial DNA (mtDNA) of the donkey and mtDNA comparisons among four closely related mammalian species-pairs. J. Mol. Evol. 43:438-446. 